\title{
Review
}

\section{Meanderings through the politics of everyday life}

\author{
Robert Porter \\ Rowman \& Littlefield International, London, 2018, x+146pp., \\ ISBN: 978-1786608741
}

Contemporary Political Theory (2021) 20, S82-S85. https://doi.org/10.1057/s41296020-00382-9; published online 27 February 2020

At first glance, Meandering through the Politics of Everyday Life, reads as a welcome yet simple revitalisation of the Situationist ethos. Situationist International (SI) is largely forgotten amongst contemporary Anglo critical thinkers on account of its allegiances to a kind of dialectical criticism, its loyalty to the constitution of some form of subject as a method of political resistance, its devotion to what some describe as an insular artistic expression and self-absorbed play as political struggle and, perhaps most significantly, the apparent unashamedly double-edged recuperative qualities of its major trajectories and mentalities. It has from both its detractors and supporters received little serious academic attention since the 1960s, when SI activity was at its strongest in France. Perhaps SI has entered the curious position of being too French for some and not French enough for others.

Porter cuts through this uncritical disquiet with the same audacious wit found in his previous works by zeroing in on the conceptual and aesthetic significance of everyday life. The reanimation of everyday life for Porter, following Situationist Theorist Raoul Vaneigem, is akin to a politics of the present. It is an attempt to live with concepts in the 'rough and tumble' of our everyday existence to avoid the haughty and humourless ramblings of more 'traditional' Western Philosophy, which largely traverse the icy waters of over-abstraction culminating in a mere representation of life. From this underlying contention-that to read and think productively is to do so with good humour, 'to bring [concepts] within our reach and into the light and life of the everyday' (p. 19) - we see Porter open out onto a mode of politics that not only provides a compelling critique of contemporary grumblings directed towards SI, but also one that offers a set of conceptual tools for fashioning a provocative affront to the banal and the mundane of everyday living.

Simon Critchley becomes the intellectual scapegoat for the general reservation concerning SI. Porter spends Parts Five and Six of his book situating Critchley as a close critical friend of Vaneigem and Guy Debord, the principal theorists of the

(c) 2020 Springer Nature Limited. 1470-8914 Contemporary Political Theory Vol. 20, S2, S82-S85 
Situationist movement, but one whose reading of the Situationist project is ultimately another foray into melancholic passive nihilism. And yet, this is a critique that is just as prone to recuperation-an SI term for a kind of capturing and re-appropriation of revolutionary practices by capital for capitalist ends-as the one Critchley warns against in Situationist politics. As Critchley eventually concedes that the Situationist movement can only now be filtered through some cartoonish montage of the affectations and mannerisms of critique, a 'mere staged and scripted performance' (p. 39) co-opted into the coding of capital, Porter reminds us that it is precisely this resignation that feeds into an over-abstraction which only serves to create distance from the critical project necessary to combat such pessimisms. If once bold articulations of resistance have been repackaged by neoliberalism as the tedious, predictable, and clichéd versions of their former selves, then to belabour this point must be equally tedious, predictable and clichéd. As Porter darkly jests, 'Nothing is more marketable and sellable in academic publishing these days than melancholic pessimism dressed up as a critical realism...' (p. 78). This resignation, then, plays out not as some inevitable consequence of capital's obstinacy, but rather as an instrument of capital itself. The conceptual artillery for Porter's critical response remains with the energetic and poetic force of Vaneigem who, all too acutely aware of the pitfalls, cul de sacs, and totalisations of recuperative logic, champions a kind of spontaneous and creative counter-recuperation. This method of critique must be passionately repeated, continually shaken, continually re-staged at the borders of those tensions where recuperation feels a constant and inevitable threat. Porter fosters a kind of engagement that insists anything can be picked up and refolded into productive modes of resistance, even (and especially) those tools appropriated by the logic of capital. Meandering through the Politics of Everyday Life, if nothing else, is a rummaging around the conceptual toolbox of critical theory and contemporary culture ask, and then show, how we might animate, weaponize, and re-order all those always-already thrown away concepts back into the foreground of political potential.

For Porter, this engagement can be best expressed through re-capturing a politics of everyday life. Porter begins with the provocation that we should not confuse the banal and mundane with the trivial and unimportant. Living with concepts in the immediacy of the present is not simply a matter of lassoing them from their lofty pedestals on high into the here-and-now, but also a recognition that the concrete phenomenon of the everyday plays out through its intimate connection with larger political totalities. It is a realisation that the fuzzy, shifting swirls of concepts, which produce the political, technological, and economic, create affirmative realities in the 'littlest' of places. Porter suggests that we take these connections seriously and acknowledge that these ideologically infused fragments of everyday life are actually 'cleverly organized' (p. 30) and constitute the basis of a definite mode of political praxis. Our analytical focus should be trained on the flows and fractures that capture the constitutive conditions which make these experiences real

(C) 2020 Springer Nature Limited. 1470-8914 Contemporary Political Theory $\quad$ Vol. 20, S2, S82-S85 S83 
to us. From this position, we might begin to see potentialised modes of expression that are counter-recuperative to this effect and, with good humour and passionate energy, to provoke a connective and creative response.

It is at this stage that, at second glance, this curiously inventive book comes into its own. To read it simply as a rehashing of old Situationist ideals, or a critique of their current pervasive dismissal, or even a gesture towards outlining a politics of its own, would be to undervalue the book's potency. These arguments, and many others, are, of course, plainly and profoundly visible. Porter wanders through his politics of everyday life, thinking apace with a whole host of philosophers, critical theorists, futurists, television personalities, and even a few cartoon characters, while imprinting some of his own everyday experiences into the mix as he expands, intensifies, and problematizes his overarching terrain. The introduction to Vaneigem's thought in Part Two is almost written as a diary chronicling Porter's own experience of reading the Situationist radical for the first time. In Part Sixteen, Porter reads together Vaneigem's orgasmic politics of the present and Gilles Deleuze's and Alain Badiou's respective philosophies of the event, bringing them to bear on an event from his own life to claim back the lived reality of the daily occurrences in which we become individually caught up, whilst maintaining the connectivity of an event in some virtual plane. In Part Eleven, Porter introduces Deleuze's 'Postscript On Societies of Control' to mobilise a discussion of the concept of 'Entrepreneurial rationality' - an over-coding, or colonisation, of business logic 'where business is brought in at every level of public and bureaucratic life' (p. 159). What begins as a rather typical rendition of the 'shift from disciplinary to control' societies quickly becomes yet another reminder to resist the urge to read these emerging structural conditions with nothing other than deflated apathy. And then, Parts 12 to 15 meander, with Deleuze, Søren Kierkegaard and tv's Alan Sugar, into the politics of the workplace and build to a joyful re-rendering of an aspect of everyday life which we might otherwise experience in gloomy alienation.

Despite Porter's mobilization of the traditional style of philosophical arguments, it feels more like he has taken these ideas as the basis of his project, put them in his pocket and taken them for a walk - an aimless wander that discovers direction through the kinetic experience of its own construction. It is an attempt not only to hold these concepts in discussion, but to write alongside them, to live with them, to energise them enough to resonate with readers so that we may forge our own connections and pathways through the text. In both style and substance, it is an experimentation on the possible, a dramatization of everyday life. The project here does not seek to gratify our desire for a sense of philosophical 'rightness' but to imbue us with a political charge. It invites us to read in much the same way as Porter did with Vaneigem — energetically, with vitality—so that we might venture out into our own daily experiences with a mode of engagement that spurs novel becomings and breaks up structural and ecological blockages. In short, Porter 
practices what he preaches. He says as much in his introduction, in which he describes the formal structure of the book as 'a series of meanderings: eighteen short, punchy, parts of a book, or bits of writing, wanderings and wonderings' ( $p$. 4). And so the parts do not establish and develop an argument in any singular or linear fashion but parry and complement each other, allowing for a more lateral and versatile reading experience than perhaps might have come from the more familiar structures found in weightier (and dustier!) tomes of political philosophy.

Publisher's Note Springer Nature remains neutral with regard to jurisdictional claims in published maps and institutional affiliations.

Jonjo Brady

Ulster University, Belfast BT15 1ED, Northern Ireland, UK Brady-J11@ulster.ac.uk 